\title{
WASTED? MANAGING DECLINE AND MARKETING DIFFERENCE IN THIRD TIER CITIES
}

\author{
Tara BRABAZON \\ University of Bolton, United Kingdom
}

\begin{abstract}
Third-tier cities are neglected in the research literature. Global and second-tier cities provide the positive, proactive applications of city imaging and creative industries strategies. However, small cities - particularly those who reached their height and notoriety through the industrial revolution - reveal few strategies for stability, let alone growth. This study investigates an unusual third-tier city: Oshawa in Ontario Canada. Known as the home of General Motors, its recent economic and social development has been tethered to the arrival of a new institution of higher education: the University of Ontario Institute of Technology. Yet this article confirms that simply opening a university is not enough to commence regeneration or renewal, particularly if an institution is imposed on unwilling residents. Therefore, an alternative strategy - involving geosocial networking - offers a way for local businesses and organizations to attract customers and provide a digital medication to analogue injustice and decay.
\end{abstract}

Key Words: third-tier cities, creative industries, city imaging, regeneration, geosocial networking

\section{Introduction}

Discovering new places is always unpredictable. Arrival is signaled by signs that mark, orient and organize a relationship between identity and location. Street signs, buildings and roads provide a shape and structure - spatial punctuation - so that familiar elements can be recognized. Footpaths and car parks are found. But there are also visual detours and iconographic accidents that confirm the shock of difference in supposedly globalized urbanity.

When I arrived in Oshawa, a small city on the outer edge of Toronto, a visual companion guided me through this urban space. This person's name was Wasted (Fig.1). Wasted left tags throughout the downtown. Fixated on the vacant space next to the retirement village (Fig.2), Wasted also tagged bordered up shops to remind downtown Oshawa residents that there are many spaces underappreciated and - indeed wasted (Fig.3).

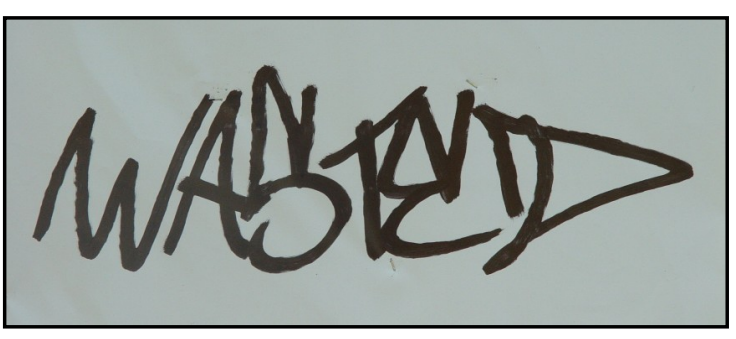

Fig. 1 - Wasted

Photograph by Tara Brabazon

I do not know Wasted's real name or gender. What I do know is that he or she provides an innovative if illegal method to read the landscape, offering alternative literacies of space and 
place (Gregory and Williams 2002). This article follows Wasted, literally and theoretically. My goal is to explore the gap between difference and decay - regeneration and decline - in third tier cities. Particularly, I overlay the potential of city imaging via geosocial networking strategies, while also logging deep infrastructural difficulties. Frequently positioned at the edge of global cities and reaching their economic peak in the late nineteenth and twentieth centuries through the success of a single manufacturing industry, third tier cities lack attention in the research literature on urban development. They do not provide easy opportunities, examples or applications for creative industries strategies. An outstanding exception to my statements here is Mark Jayne's study of Stoke, which demonstrates the failures in a glib application of creative industries strategies that have operated effectively in global and second tier cities (Jayne 2004).

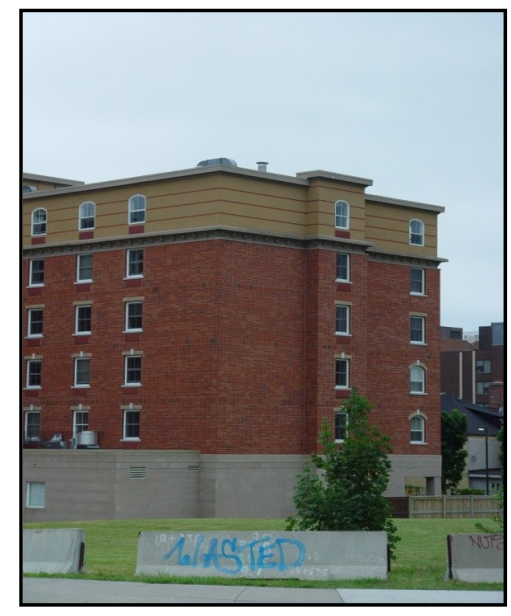

Fig. 2 - Wasted Space

Photograph by Tara Brabazon

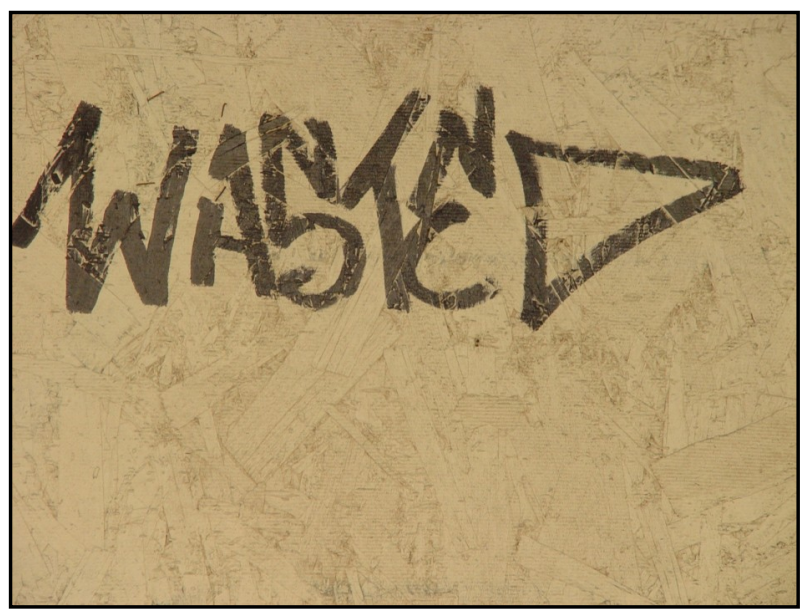

Fig. 3 - Closed Space

Picking up Wasted's trajectory and intent, my article explores city imaging for third tier cities, with specific attention to the distinct and particular benefits of geosocial networking, even amidst the failure of physical infrastructure. The study commences with national imaginings, drilling down to city imaging initiatives, through to a focus on the third tier and geosocial networking. A key example remains Oshawa, located just outside Toronto in Canada. It is an industrial city losing its historical role and yet unable to claim a new identity and path.

\section{Imaginings}

Nations are complex imagined communities (Anderson 2006). Postcolonial nations in particular confront challenges in reclaiming the languages, faiths, structures and traditions burnt and destroyed by the colonizers (Nandy 1983, Prakash 1995, Said 1978, Spivak 1988, Spivak 1990). Canada's imaging is rendered more intricate and contradictory through the management of the dual (and dueling) colonizations of the United States and the United Kingdom. Theories of whiteness in settler societies with a history of dispossession of indigenous people, like Canada, Aotearoa/New Zealand and Australia, are particularly volatile. Being both colonized by the British and colonizing indigenous peoples creates volatility in the construction of identity and history (Young 1990). In postcolonial countries, the nation is a structure, boundary and ideology. It operates as a node of resistance, creating policies that support and protect cultural 
industries such as music, film and television. This process of protection of cultural productions can be valuable but may also produce extremely conservative results. Patriotism can spill into xenophobia. Such national imaginings also wallpaper over destructive internal differences. The divisions between east versus west, north versus south, Toronto versus the rest, render the landscape ideologically volatile. Creating a sense of being and identity is intimately connected with place. Each location enables particular geopolitical strategies that frame behavior, subjectivity and daily patterns of movement, including socializing, producing, consuming and learning.

There are many ways to dissect space. Similarly, there are many modes and platforms on to which information and instructions are provided in how to move into and through a location. Sign systems are overlaid onto a landscape and reinforce imagined boundaries, granting both content and credibility. Flags, anthems, national colours and sporting teams ${ }^{1)}$, alongside media policies, configure and develop ideas of sovereignty and difference. This means citizens can maintain a national allegiance when disconnected from the landscape. Yet a reality remains: nations are hooked into the global economy and maintain a network of cultural, economic, political and social relationships, particular through migration.

Cities create competing allegiances, identities and ways of dividing and sharing space. Any understanding of a national culture has to work its way through intertextual networks, balancing not only national culture with international culture, but also national with local, and national with regionality (Walby 2003). The mobility of digital information only widens and deepens this spatial dialogue. Jim Shorthose and Gerard Strange confirmed that, at its most general level, this new economy can be identified as being increasingly global; increasingly about intangibles such as knowledge, information, images and fantasies; and increasingly decentralized, and characterized by networks and flexibility (2004, p. 43).

Shorthose and Strange recognized that national imaginings are being challenged, bent and transformed through the engines of the "knowledge economy, ${ }^{2)}$ which is built on the mobility of people, ideas, information and capital. Therefore, it is necessary to rub down these national narratives and imaginings to discover the digital exfoliations of urbanity.

\section{City Imaging}

City imaging is a phrase with resonance in urban planning, marketing, tourism and creative industries. It connotes a combination of place and iconography, with the goal of spatializing economic development through metaphors and policies (O'Connor and Wynne 1996). While phrases like the Creative City, cultural quarter and cultural cluster (Cornford and Charles 2001) have been deployed by Charles Landry and others (Landry and Bianchini 1995), such

1) The relationship between sport and urbanity is important. However it is necessary to note that second tier cities in particular develop a cultural and sporting infrastructure that can be promoted through tourism. Initially, the National Football Museum in the United Kingdom was based in Preston, a third tier city. However, through years of struggle, it was moved to Manchester. This short history tracked a movement from a third to a second tier city. To monitor the early history of the Museum, please refer to Brabazon and Mallinder (2006). To see a powerful study of community development in cities through sport, please refer to Brown, Crabbe, Mellor, Blackshaw, Stone (2006).

2) I have intentionally used inverted commas around 'knowledge economy' for its first appearance in this article. It is now a compound noun with a reasonably agreed definition. However I wished to emphasise that it is a shift in both policy and thinking about how money is made in a post-fordist, globalized economy. To track one trajectory of this debate, please refer to Charles Leadbeater's Living on thin air (1999). 
initiatives - at their most basic - probe, explore and develop advertising campaigns for cities and regions, rebranding troubled, static or declining locations and facilitating entrepreneurial initiatives to reinvigorate buildings, shopping complexes and event management (O'Connor and Wynne 1996). The assumption is that creative industries will - intrinsically - regenerate declining areas through innovative reconfigurations of 'quality' culture, access to art, and entrepreneurialism (Kunzmann 1995). The result is a heady mix of economic, social and cultural development.

City imaging is based on assumptions of a place, amalgamating the colours, sounds, smells, textures and history that arise when a particular urban environment is mentioned. The mental image of Detroit is different from Singapore. Tokyo is distinct from Glasgow. Some senses are more strongly involved in the imagining of a city than others. The application of these senses in summoning or denying the visual, sonic, olfactory, tactile and taste-based representations of a place is dynamic, unstable and unpredictable. The task for policy makers, urban planners and the tourism industry is to use and transform this image, to market the city as a tourist destination for music, sport (Misener and Mason 2006), beaches, books (Brabazon 2011) or relaxation.

Cities are complicated cultural formations. They wear history and are worn down by it. After industrialization, cities became places of fear, where working class people may gather, collectivize and resist inequality. Books such as Matthew Arnold's Culture and Anarchy (1869) capture the fear of change and a desire to use 'culture' as medication, or indeed, sedation, for resistance, revolt and riot. Through the process of industrialization, cities morph, expand and corrode, revealing uneven development in education and health facilities, poverty and volatile overemployment, underemployment and unemployment in response to production and consumption. Structures are built to create or enhance social exclusion (Manley 1996). For example, the Thames in London separates the city, organizing spaces, buildings and suburbs socially and economically.

All cities share a great deal: a transportation network, pollution and commercial hubs. Differences are instigated through immigration, size of population, geographical specificities, weather and economic policies. One strategy to organize cities for both research and policy development is to position them into tiers, based on size, influence, branding and impact. Global cities are the spine of the international economy, with a huge multicultural population, housing the international headquarters of corporations and diverse modes of production and consumption. Such global cities can be listed with ease: New York, Toronto, Mumbai, Paris, London, Berlin, Madrid, Sydney, Auckland, Tokyo and Cairo. They have much in common. This sameness is matched by an intense connectivity and mobility (Florida 2005). After September 11, global cities like New York and London became places of fear, confusion and terrorism, with a targeting of transportation networks (Redhead 2006). The point of globalization is that it renders global cities homogenized, sites of sameness. Indeed, Saskia Sassen - the key theorist of global cities - argued that they are "de-nationalized" (Sassen 1991). Global cities are disconnected from national imaginings and form relationships with other global cities (Bianchini 1991). They hold a particular function in the global economy. The premise of such an argument is that New York has more in common with Toronto and London than New Orleans or Las Vegas.

Non-global cities, not surprisingly, describe all the other cities that are not global cities. The most researched cities in this category are situated on the second tier. They are sites of difference, including divergent popular culture, tourism, industries and economic development. These cities, like Vancouver, Brighton, Wellington, Perth, Osaka, Dunedin and Düsseldorf, are 
very different from each other. Banking and corporate headquarters are not located there. Diverse industries fuel the cities. They reveal diverse and frequently distinct ethnic and immigration histories. These non-globalized differences are the foundation for tourism. While global cities hold many remarkable similarities, Dunedin is very different from Vancouver. These distinctions sharpen the market and marketing. Without these diverse and marketable landscapes and identities, tourism does not function. Because of the unusual histories and size of second tier cities, they become known and branded for a particular moment or event. The Beatles and Liverpool is one example. Seattle and Nirvana is another. Wellington, Lord of the Rings and the Weta Workshop is a further case study of a cultural intervention providing wider social and economic opportunities.

The music industry in particular is based on the categorization (and marketing) of difference in genre, time and space. When considering Düsseldorf, Sheffield and Manchester, music has been used with great effectiveness to shift the imaging of various cities (Brabazon 2005). Certainly global cities like New York and London take all the creative, critical, institutional and economic attention. Bands and DJs who are successful in these places are highly visible to policy makers and the music industry because the corporations are based in these cities. Any minor success is quickly recognized. The A\&R personnel of record companies are based in these locations. However musicians and artists not resident in these centres have more time to develop a sound, skill base and experience without preliminary pressure. They can improve musically, grow up, gain a fan base and support structure. By the time recognition does arrive or at least a record contract - they are more experienced from managing a smaller city's venues and audience. Oasis and The Beatles ${ }^{3)}$ are clear examples of this argument. Secondtier bohemia - in San Francisco and Seattle - can be branded (Brabazon and Mallinder 2010).

Some global cities like Auckland are so spread out that it is very difficult to bring a group of people together in space. For a music industry to function, there must not only be venues to play, but enough people to attend the gig, often enabled through a functional bar and public transportation networks. The strength of second tier - or non-global cities - is clear. Located outside the matrix of global cities, the smaller size of the urban environment enables audiences, communities and fans to be formed (Lee 2002). This economic modelling of cities, particularly on the second tier, is increasingly important. Ann Markusen, Yong-Sook Lee and Sean DiGiovanna argued that "second tier cities are the most remarkable new regional phenomenon in the late twentieth century" (1999, p. 335). There are many reasons for the innovations that jut with seeming predictability from second tier cities. They are more malleable to urban planning and city imaging strategies. Manchester and Sheffield are the archetypes of this innovation and intervention. Activating and marketing sport, music, tourism and technological change has meant that new relationships are forged between city imaging and economic development. Markusen, Lee and DiGiovanna described them as "sticky places in an increasingly slippery world" (1999, p. 335). Because of the population and geographical size, cultural and creative industries policies can be more targeted, appropriate and specific (Sweeney 2004). Therefore the most effective and precise way to both study cities and create efficient policies is to find relationships between them. Structuring them in tiers is a way to create this specificity.

While the second tier cities have both economic and social potential, third tier cities are not only

3) The Beatles are particularly interesting as they not only played Liverpool venues in their early career but travelled to Hamburg for extended residencies. In other words, they were formed and based in one second tier city and improved their musical abilities and sharpened their capacity to perform in front of a live audience in another. 
neglected in the research literature, but are lacking infrastructural and policy support (Bell and Jayne 2006, p. 2). These cities require the most intervention. The impact of global cities on the regions encircling them is that they pull people, industries and money (Scott 2001). The economic and social scale and size of global cities ensures that the surrounding areas are often post-industrial wastelands. It is difficult for these areas to gain an identity and image. These outlying regions often form third tier cities. These cities are incredibly diverse in shape, population and economic 'development.' Erickcek and McKinney located and categorized eight types of small cities: 1. Dominated by an older industry in decline. 2. Private-sector dependent, with little public sector employment. 3. Dispersed geography and function. 4. Company towns attempting to survive when a company leaves. 5. University and college cities where graduates leave after graduation. 6. Company towns surviving after the company leaves, but with a remaining social purpose. 7. Cities growing through the engine of the new economy and creative industries. 8. Cities growing through university/government/business clusters (Erickcek and McKinney 2004).

This is a strong rubric to map and categorize third tier cities. A key book in this under-researched field that captures this diversity is the edited collection from David Bell and Mark Jayne: Small cities: urban experience beyond the metropolis (2006). The contributors investigate the consequences of inter-city competitiveness. The overarching argument from the researchers is that the strategies that have worked in San Francisco and Manchester are not (necessarily) applicable to Stoke, Mandurah, Invercargill or Oshawa.

Therefore, unable to replicate the strategies of second-tier cities like Manchester, Osaka or Seattle and without an intervention from public or private investment or higher education institutions, third-tier cities stagnate or decompose. The question, raised by Beth Siegel and Andy Waxman, is whether this decline is unstoppable. Unfortunately for these cities, many of the sources of strength that they drew upon in their heyday are now disadvantages in the New Economy. For example, their rich industrial heritage was the result of large, densely built factories that were constructed to take advantage of the transportation modes of the day waterways and railroads. In the New Economy, employers prefer an entirely different sort of location - sprawling one-story buildings near highways and advanced telecommunications lines, or in larger, more vibrant cities. As jobs moved out of these small cities, a host of other problems followed: declining population, loss of the middle class, abandoned mill buildings with environmental legacies, struggling downtowns, a shrinking tax base, and fewer employment opportunities (Siegel and Waxman 2001).

Jobs vacate these small cities, along with population. Downtowns struggle. The tax base reduces. The difficulty in retaining young people and attracting new residents is profound. Facilities and infrastructure follow the population. These third tier cities exist throughout the world and the strategies to enable their recovery are diverse. Superficial attention to branding and city imaging are not sufficient. Siegel and Waxman realized that, "while the data demonstrate that third-tier cities are having difficulty transitioning to the New Economy, a more thorough understanding of these cities is needed, an understanding that goes well beyond statistics" (2001). They are correct. For the purposes of this present article, I propose a fourlayered strategy for this understanding. Firstly, it is important to understand the specificity of the city's history, noting the period of its greatest economic and social success, along with its causes and consequences. A second stage is to recognize the present environment and reality of living in this city. Thirdly, it is beneficial to explore the similarities and differences with other third tier cities around the world, noting effective and inefficient strategies for change. Finally, a city modelling imperative, where applicable strategies in one city are then attempted in another, may provide an imperative for growth or a temporary tactic to sustain a current situation while 
other policies are discovered and researched.

Many third tier cities gained a successful single industry in the manufacturing and industrial age. Flint and Oshawa manufactured motor vehicles (Macaluso 2012). Napa (still) makes wine. Blackpool was a destination for working class tourism. Rockhampton in Australia was a service hub for the cattle industry with a huge meat works. These cities are rarely known beyond their nation. They were not marketed or branded. So third tier cities were successful in the manufacturing/industrial age, but have failed in the new knowledge economy. The housing and transportation in the third tier is inadequate (Grieco and Raje 2004). The infrastructure was based on factories and the construction of small homes for the workers to service the industry. The telecommunication systems and mobile networks are inadequate. Therefore, the jobs reduce, and employment in 'the new economy' - particularly in the service sector, creative industries and education - moves to global and second tier cities (Barnes and Hutton 2009). Because of the lack of employment, the population is declining, the middle class are leaving, and health and educational facilities are reducing. Abandoned and derelict buildings proliferate. Environmental problems, hazards and pollution result from the after effects of industrialization. Downtowns are deserted. Shops close because of the lack of population. Young people leave for global cities where work and leisure opportunities are a draw card. What remains are commuter cities that are often desolate, decomposing and decaying. As an example, Luton - a third tier city - is $44 \mathrm{~km}$ (or 27 miles) from London. Brighton - a second tier city - is $88 \mathrm{Km}$ (or 55 miles) from London. That slight increase in distance from the global city creates just enough space for separation and difference which is integral to the development of the creative industries. Brighton is a second tier city of 220,000 people. Luton has 180,000 people. Luton is an industrial wasteland. The talented, skilled and educated move to London. The affluent live in Brighton. Although it is only slightly further away, it is still within one hour of London by train. This proximity means Brighton has an independent identity. Luton struggles to maintain one.

Oshawa in Canada has a population of 140,000, but from such a size and geographical position, it is difficult to resist the pull of Toronto. The relationship between Oshawa and Toronto is not unusual. It is part of the history of working class people. Through the tandem forces of industrialization and urbanization, the building of industries and the construction of cities was aligned. Cheap housing was created in the middle of cities so that workers could operate the equipment in factories. Through the nineteenth century, the white collar workforce moved into the suburbs, enabled first by the train and then the car (Featherstone 2004). However this narrative of urban sprawl changed later in the twentieth century. The affluent moved back into cities, living in lofts and condominiums. Inner cities were upgraded and updated for urban professionals (Butler and Lees 2006). This process displaced the working class people living there. Governments therefore created housing estates at the extremity of cities. This was an effective option in the 1960s and 1970s because they were serviced by trains and buses. But as public services started to decline, the hospitals and schools were closed in these outlining suburbs. Fewer buses and trains were available to transport people to work, education or leisure. Concurrently, Edgelands - the "waste places" (Farley and Roberts 2011 , p. 6) at the metaphoric moat of cities - demonstrate the neglect of public spaces and the mismanagement of industrial ruins.

Such urban narratives and differences are the basis of city imaging and integral to place branding. Obviously the branding literature is wide and interdisciplinary, and only minimally conflates with city and regional development. However the imperative remains 'improvement' and 'progress.' As Evans states, "Frequently, regeneration programmes are developed without reference to, or inclusion of, incumbent arts and cultural groups, or past heritage associations / 
communities. This arises due to the different nature and perspective of the 'regenerators' and community-based activity" (2005, p. 971). He realizes that, "Indeed, in the areas which are the subject of extensive regeneration, it is presumed that quality of life and, by association, indigenous culture, is poor and needs 'improving'" (2005, p. 971). Therefore, a city imaging process can emerge from a disrespect and disregard of urban history and injustice, and configures a shiny if brittle shell of modernity. A better model emerges from Jonathan Gabay, founder of Brand Forensics, who stated that, "Branding a city is not just about the logo but the intricate details - as small as clean streets and as deep as getting a city's residents to feel proud to be brand ambassadors. When citizens are proud, visitors are encouraged to find out what the fuss is all about and then tell the world" (Salman 2008). He recognizes the importance of ownership and investment in the image, and the depth with which the changes in city imaging and branding are recognized by those who live in these spaces.

For example, Hazime explores how Qatar and Abu Dhabi are challenging globalization and sameness by building their cities into brands (2011). In the Middle East, following the example of Dubai in the UAE, the goal has been to build enabling airlines with emphasis on event tourism. Many of the UAEs do not have the resources of other nations in the Middle East, so they are reliant on tourism, museums, education and sport. The successful programmes in Qatar and Abu Dhabi have also utilized the speed and potential of digitization. Their initiatives foreshadow my discussion of geosocial networking later in this article. It is easier and quicker to brand cities and regions through digitization, particularly when mobilizing the read write web and user generated content. This branding matters for sustainable employment, but a sense of belonging and identity cannot be imposed or faked. It must be tethered to the experiential reality of living and moving through a place.

While such social relationships are important, the economic modelling of cities is becoming even more urgent, particularly after the global credit crunch and recession. The history of cities, as sites of political struggle, fear and change, is being rewritten. Cities were important to radical politics. Marx and Engels saw the conditions in the cotton mills in Manchester. Some of the most radical writers of the last one hundred years - Robert Tressell, Raymond Williams, Richard Hoggart and EP Thompson - watched the changes to people and the landscape, and wrote their politics through the city. Urbanity was an actor and agent in social change. Such a function is being overwritten: cities have become sites of consumption. Such attention to the marketing of place not only sells a city, but aims to promote local economic development. As Walker argues, cities create brands for tourism (2010). But for such a strategy to operate, there has to be something distinctive to sell the city to visitors. Third tier cities in particular, of which Oshawa is an example, lack this clear marketing focus and require assistance and attention. Cities rarely improve from 'bottom up' strategies from citizens. Planning and investment for facilities, leisure activities, entertainment, education and work are all required (Hollands 2002). Such interventionist policy initiatives first emerged in (post)industrial England, where it was necessary to re-inscribe the landscape and permit new economic strategies to develop.

Cities based in manufacturing suddenly and desperately required a new purpose. Sheffield, with its history locked into manufacturing and steel, moved from labour intensive older industries and embraced digital and creative industries. Not only music production, but film making, publishing and the creative arts are now part of the new Sheffield. Similarly, Manchester is a post-industrial city. It was reliant on the textile mills, but once these closed, new reasons for the city's existence had to be found. As Dave Haslam realized, there's an identity crisis at the heart of the story of the modern city. Manchester, like England, is now re-creating itself, looking for a new role, a life without manufacturing industry. Like a middleaged man made redundant after a lifetime in a factory, Manchester is either facing years 
drawing charity, welfare and government handouts, or it's going to retrain, reorganize, and find something to keep it occupied $(1999$, p. xi).

Reorganize it did. The phrase knowledge economy started to describe the high concentration of Universities, academics, teachers and students in the city. Leisure facilities and successful sporting teams like Manchester City and Manchester United enabled day trips through the cycle of home and away matches that facilitated local tourism ${ }^{4}$.

These cities discover new roles and functions, creating new opportunities. Networks of cities generate an active regionalism. Will Alsop proposed a 'Supercity,' spanning from Liverpool to Hull along the M62 (2005). While basing a regional strategy along a road weds regional development to automobility and questionable sustainability, Manchester is becoming an important transportation hub with a large regional airport serviced by a train line that provides alternative entry points into the United Kingdom, beyond the dominance of London Heathrow and Gatwick. Manchester has an historical role in forging such regional connectivity: it was the hub of the first water navigation with the Bridgewater Canal in 1759. The point of a transportation policy therefore is far greater than managing traffic congestion and gridlock. It enables urban regeneration and regional relationships. A connected city is a successful city.

The problem with many cities, including Oshawa, is that they are car-dependant. It is very difficult to move around these spaces. This is particularly significant if airports are not positioned on train lines (or train lines do not integrate with airports). Pearson Airport in Toronto and Perth Airport in Western Australia are two examples where disconnection between modes of transport creates both social inconvenience and an economic cost. The effective integration of planes and trains around Gatwick and Manchester Airports and the less successful but still functional connectivity of public transportation to Heathrow show the potential and opportunities of aligning systems of movement through space.

There is a strong link between transportation and poverty (Sanchez 2005), with incredible effects on education, housing and available employment. Therefore in declining third tier cities, men and women are trapped. It is difficult to find work or attend university. It is also challenging to support good health (Marber 2000), leisure and fitness (Noiman 2009), because of a lack of availability of quality food and supportive sporting infrastructure (Marvin and Medd 2004). Indeed Maurice Patterson has created a strong short book, titled Inner-City Diet, that shows the

4) The importance of the Premier League in this economic development requires a separate research project. Significantly, the Premier League is dominated by London-based (global city) teams such as Arsenal, Chelsea and Tottenham Hotspurs. However second tier cities dominate the rest of League. The value to third tier cities if they can break through from the Championship is difficult to calculate. Not only is there the media revenue and the tourism generated from away fans coming to the city, but the international promotional opportunities in terms of city branding is invaluable and - indeed - difficult to value. Similarly the cost when teams do not come up or rebound between the leagues is high. Bolton, Southampton, Portsmouth, Wigan, Blackburn and Blackpool show both the potential and cost of third-tier cities competing - via sport - in the competitions of second tier and global cities. One poignant case involves Preston North End, the Premier League's first championship winner in 1889. The National Football Museum was initially attached to Preston North End's ground. However controversies over entrance fees and endless questioning of why it was positioned in Preston resulted in it being moved to Urbis in Manchester. This is a straight- forward example of the movement of industries from a struggling third tier to a booming second tier. However Preston North End was very close to promotion into the Premier League in the early 2000s. The hypothetical question remains, what would have happened if away fans from the Premier League teams were drawn to the ground to watch the match, but also were able to enter and enjoy the museum? The potential of sports tourism and sports media to city imaging initiatives for third tier cities is an important area of future research. 
cost of injustice on the health and fitness of residents (2009). Therefore the poorest people who most needed assistance had little chance of receiving it because of a lack of a supportive and enabling built environment (Handy 2002).

There are opportunities for these small cities to recover and bloom. Some cities adjust to change. Others do not. Landry presented some shape to this pattern of success, failure and transformation. Successful cities seemed to have some things in common - visionary individuals, creative organizations and a political culture sharing clarity of purpose $(2004$, p. 3).

The problem is that there is no checklist for recovery. Further, the transferability of strategies between struggling cities is debatable (Baker 2007). What may work in Oshawa will not function in Hastings. What operates in Galway may not be appropriate for Aberdeen. It is important to research and discover what has worked well in other cities. It is necessary to translate and migrate data for new conditions. Certainly, the problems in these third tier cities have been listed. Siegel and Waxman reveal the scale of the challenges.

- Out of date infrastructure

- Dependence on traditional industry

- Transformation of their human capital base

- Declining competitiveness within their regions

- Weakened civic infrastructure and capacity

- More limited access to resources (Siegel and Waxman 2001).

There are strategies to manage these difficulties, but they require funding. Sustained and planned attention in the long term is required on modern transportation and communication infrastructure. While third tier cities are small and unable to mobilize the economies of scale, the capacities for teleworking and e-commerce in wireless environments can move local ideas and products into second tier cities and beyond. Therefore the final two sections of this article explores the specificity of Oshawa and the potential of geosocial networking to digitally reconfigure and reboot analogue injustice.

\section{Third-tier cities: the case of Oshawa}

Narratives of post-industrialization decompose cities, cracking the foundation of urbanity, accessibility and social justice (O'Regan and John Quigley 1998). As argued in the last section, between the $19^{\text {th }}$ and $21^{\text {st }}$ century, poverty moved from the inner city to the outer ring of large cities. Effective public transportation systems matter in minimizing this social rupture and damage: they are the key to economic and social mobility (Urry 2003). Without planning and considered attention to movement patterns of people, goods and jobs, Paul Farley and Michael Symmons Roberts' Edgelands are created. Walking through Wolverhampton, a third tier city looking for a purpose, they realized that, "new things are very easy to get hold of, despite the fact that we British don't seem to make many of them anymore. In fact, the collapse of our old, physical industries into virtual industries is one of the oft-repeated signs of our troubled times. This has come at a huge and well-documented cost to individual lives, social cohesion, community identity. But does it have a cultural impact too? Walk around the edgelands of Wolverhampton and you see a landscape struggling to shape itself to a world of virtual industry" (Farley and Roberts 2011, p. 54).

It is easy to focus on the clean, digitized new economy. However the rusting relics of the industrial past remain. Within these edgelands, decay anchors the downtown region of cities throughout the world to a past of industrialization rather than a future of digital design and skill development (Fig. 4). 


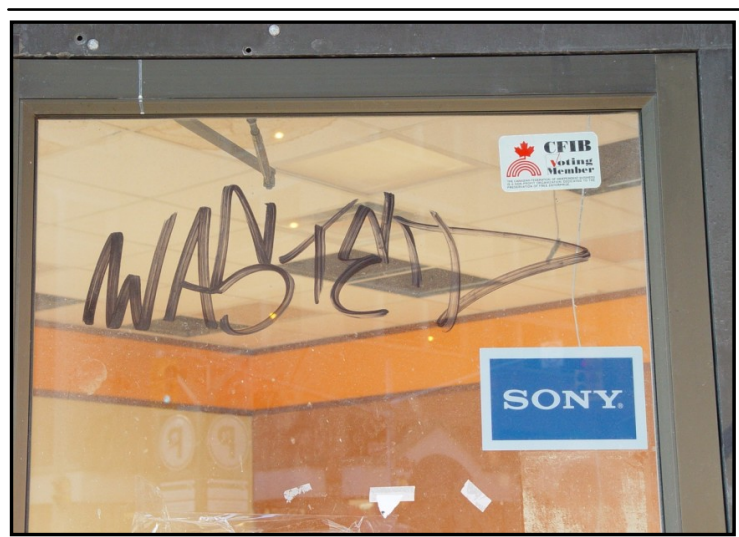

Fig. 4 - Wasted retail spaces Photograph by Tara Brabazon

Gary McDonogh and Marina Peterson realized that the word downtown "evokes intensities at the core of urban life, space and capital" (Peterson and G. McDonogh 2012, p. 1). The description of 'intensities' is fundamentally appropriate, capturing the hostility, fear and decline of downtowns alongside the potential for development, in the many manifestations of that word.

They capture the abandonment of the city, policies for rejuvenation and the mixed use of urban environments during the day and night. Further, there are an increasing number of university 'downtown campuses,' using the land and buildings to enable expansion of higher education. From his Canadian experience, Leo Groarke, former Dean of Wilfrid Laurier University's campus in downtown Brantford Ontario, wrote Reinventing Brantford: A university comes downtown. He noted challenges in enrolment and the complex relationships formed in multi-campus institutions. Similarly, the University of Windsor, at the cusp of the Canadian and US border, is planning to relocate Social Work, Visual Arts and Music to the downtown. Brock University is constructing a cultural arts centre in St Catharines. Grant MacEwan University in Alberta is rebranding itself as "Edmonton's downtown university." Claudio D'Andrea confirmed the reason for this expansion. Many see these campuses as solutions to the problems of decaying downtowns in smaller Canadian cities. Universities, in turn, are reaping community goodwill - as well as badly needed expansion space (2012).

Oshawa undulates through this narrative of decline and decay, potential and opportunity. It was reliant on a single industry that employed working class men. Then the car industry declined. The purpose, place and role of Oshawa in both Ontario and Canada are unclear (Straw 2010). One opportunity to change this story emerged through the University of Ontario Institute of Technology (Fig. 5).

Higher education gives such cities a new industry and the opportunity for residents in the Durham Region to gain a degree. However history matters. It pulls and drags. As John Quelch and Katherine Jocz realized, "place determines how consumers interact with a product or brand" (Quelch and Jocz 2012, p. 3). While students are not consumers and universities are not a

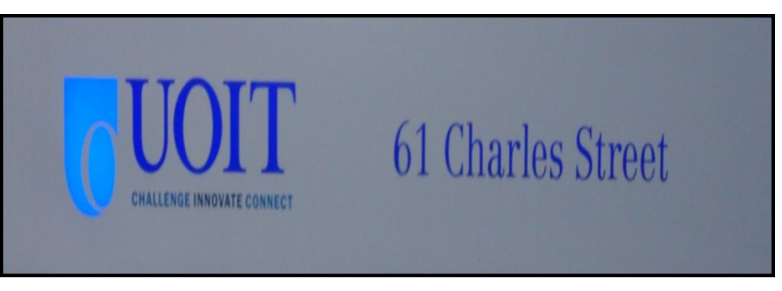

Fig. 5 - UOIT's Downtown Campus Photograph by Tara Brabazon product, the corporatization of higher education mobilizes wider brand management strategies. The reputation of Oshawa as a declining General Motors City - Canada's version of Flint in Michigan - has an effect, alongside the (over)reported violence, rapes and drug use. Less than one minute from a UOIT building is an undeveloped GM site, still showing the residue and scars of its industrial past (Fig. 6). 


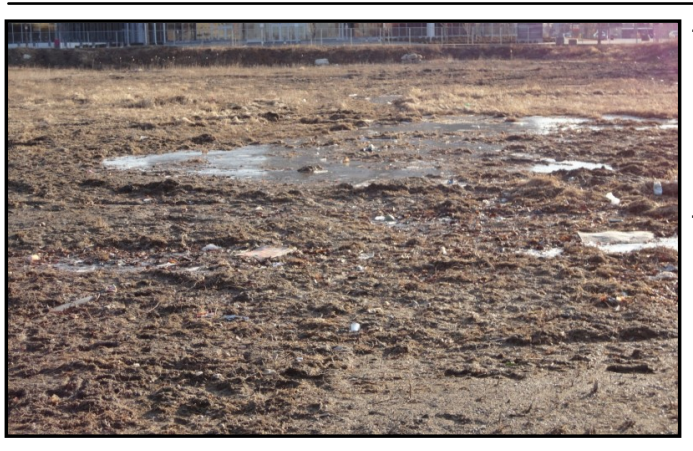

Fig. 6 - Industrial Residues

Photograph by Tara Brabazon

Therefore while a university can provide an important mechanism to re-image a city, the history of Oshawa is deleterious and seeps into the present. Brand management can mask some of the challenges, but it is a temporary mechanism. Significantly, the institution was named the University of Ontario Institute of Technology (Fig. 7).

Using the provincial rather than the city's name was a way to render the university's location ambiguous in space and disconnected from real geography and reputation. While this was a short term strategy, the longer-term consequences are that not only is the campus dislocated in space but it can have little positive impact on the rebranding Oshawa. Place remains, as Quelch and Jocz realized, "a metaphor of status, whether social or professional. By definition, the place we want to be is inspirational" (Quelch and Jocz 2012, p. 28). Oshawa is not inspirational, and Ontario has many universities. Therefore a University of Ontario is attempting to mask the complex, negative, confused and under-developed re-branding of Oshawa. The competition for students is intense. The University of Toronto is one hour by train from Oshawa. The University of Trent already has a campus in Oshawa. However the naming of a University of Oshawa Institute of Technology may have confronted too many challenges, paradoxes and contradictions for student marketing and retention. Yet third tier cities such as Guelph and Windsor have claimed, linked

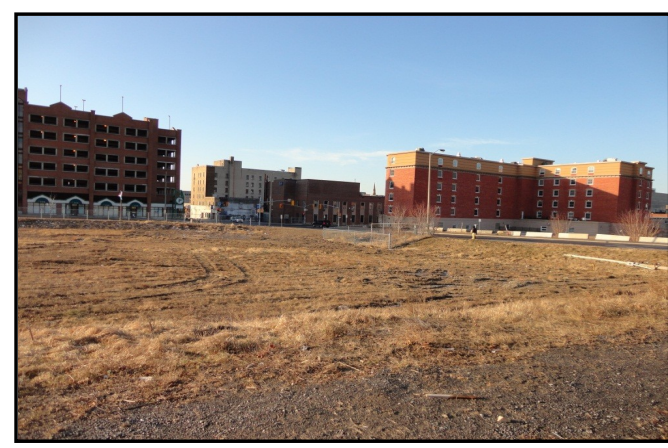

Fig 8 - Neglected Space

Photograph by Tara Brabazon

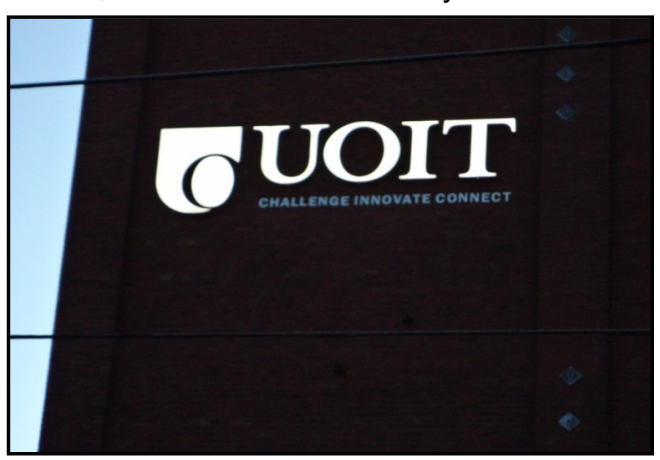

Fig. 7 - Ontario, not Oshawa

Photograph by Tara Brabazon

and named both place and university. There is much remedial policy and institutional work to conduct in Oshawa, both inside and outside the university. This concern is made worse because the histories written about Oshawa are rare and poor quality. M. Mclntyre Hood's Oshawa: Canada's Motor City was written in 1968 and presents an unreconstructed 'great men' version of history, propelled by a neocolonial narrative, including a first chapter titled "Before the White Man Came" (Mclntyre Hood 1968, p.1). While local histories tend to be uninspiring and celebratory, there has been little intellectual revisionism of Oshawa to create momentum for innovative social and economic developments. Oshawa does not enable or encourage a concise or easy regeneration story. While Toronto is well serviced by schools, libraries and hospitals, Downtown Oshawa is severely neglected (Fig. 8). 
The two framing buildings around this wasteland are a car park to the left and a retirement village to the right. Such vistas capture the problems punctuating the outer ring of global cities. Julian Brash described "downtown as [a] brand" (2012, p. 257). The question is how this branding of Oshawa is invested with both meaning and value. But there are international case studies to deploy that may be of use in creating models of development for Oshawa.

Oshawa made one crucial, productive and courageous step, moving from a manufacturing industry to the knowledge economy. There are however profound infrastructural problems confronting the university, staff and students. Founded in $2002^{5)}$, the first students were enrolled in 2003. The northern campus was opened at this time. A downtown campus later followed in 2010. The enabling legislation for the formation of the university reveals two key ideologies: the goal to provide an opportunity for further education students to attain a university degree and an imperative to 'service' the Durham region. From this legislation, complex relationships between UOIT and Durham College, the FE institution with which it shares premises, is clear. Sharing a northern campus, library and technological infrastructure has meant that a problematic confusion has emerged between further and higher education. While nations such as Australia and the United Kingdom have national quality assurance protocols such as the QAA and the AUQA that were particularly valuable in establishing the value, level and standard of 'new universities,' such a national network is lacking in Canada. A few doctorates have been awarded in the sciences and engineering, with none in education, the social sciences or humanities. The Dean of Graduate Studies lacks experience in institutions beyond Ontario. For the Vice Chancellor Tim McTiernan, this is his first post at this level. Similarly, Deans of Faculties have not held the title or post before their current appointment at UOIT. This creates the precarious combination of an inexperienced management tier and a new institution. Therefore, provincial attention will be required to verify quality assurance, curriculum design, external examination and professional development, particularly in teaching and learning. The majority of staff hold no track record or expertise in doctoral supervision and research training. This means that the crucial trajectory for growth in graduate education will be difficult to negotiate or build because of a lack of experience in trans-institutional examination and quality assurance. The key difference between further and higher education is the capacity to award graduate qualifications. The longer the confusions between further and higher education remain between Durham College and UOIT, the less opportunities will emerge to develop a reputation for excellence in doctoral candidature management.

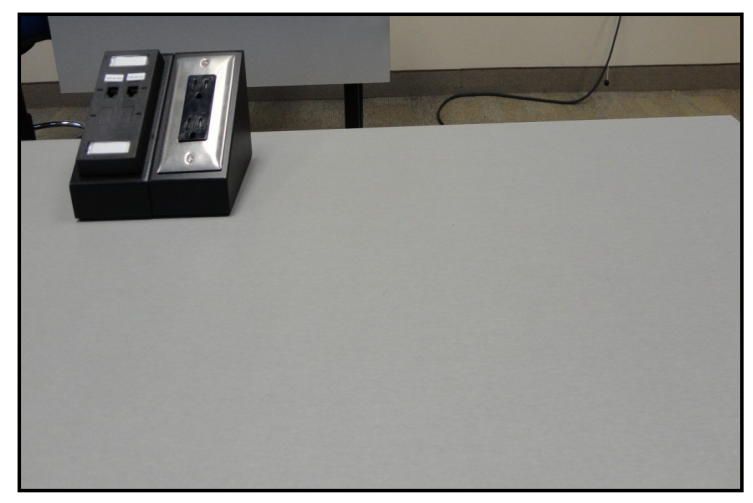

One further oddity emerged in the branding of this new university in a city with declining industries and manufacture. The labelling of the campus as a "laptop university" has wedded the delivery system of teaching to an increasingly outdated hardware platform. The focus is on the hardware rather than the learning (Fig. 9).

Fig. 9 - Laptop Learning?

Photograph by Tara Brabazon

5) The enabling legislation was the University of Ontario Institute of Technology Act 2002, http:// www.e-laws.gov.on.ca/html/statutes/english/elaws statutes $02 \mathrm{u} 08 \mathrm{e.htm}$ 
Each student must lease a Lenovo Thinkpad at the start of their degree, with options to buy it before graduation. In marketing and branding terms - even before working through considerations with quality assurance - to attach a mitigating adjective to the word 'university' is unwise. Oxford is not a "book University." When Duke distributed iPods to their first years, they did not rebrand themselves as the "iPod University." Therefore, mistakes were made in an attempt to brand the institution. In a desire to be modern and different, the institution demonstrated the exact opposite, wedding itself to both technological determinism and obsolescent hardware. If the history of educational technology teaches researchers anything then it is this: what begins as fresh, innovative and edgy quickly evolves to tired, redundant and banal.

The Downtown campus was a fascinating proposition. As the graffiti artist who inspired this article realized, the downtown is "wasted." The capacity to purchase derelict buildings and reinvest them with purpose is a powerful and important project. The Regent Theatre was renovated, used for lectures during the week and performances on weekends and weeknights (Fig. 10).

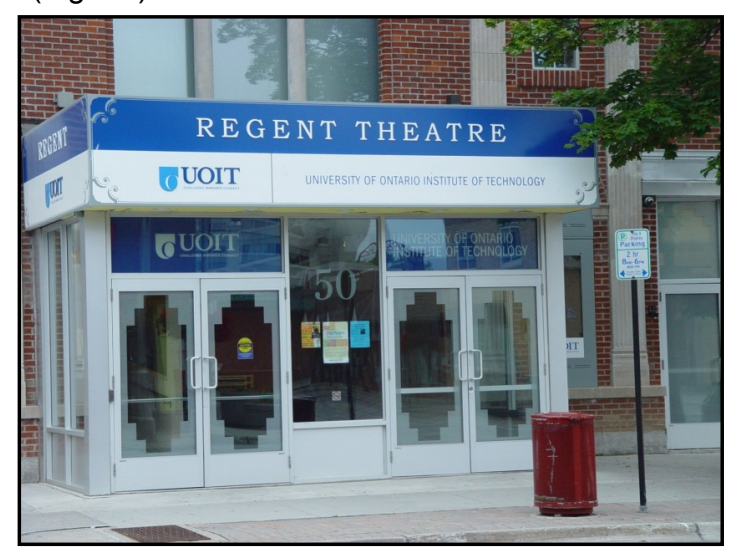

Fig. 10 - Regent Theatre Regeneration Photograph by Tara Brabazon
However the renovation was flawed. Within one year of its opening, the building had to be closed for repairs to the structure (Cole 2012). A more successful transformation was to the Alger Press building, on the corner of Athol and Charles Street, which was retrofitted for lectures, teaching rooms and the library. In its earlier history, it housed a textile manufacturer and later, the Canadian Electric Lamp and Canadian Knox Glass Company. General Motors used it for a short period during the second world war. But the building most famously housed Alger Press, which produced The Oshawa Telegram, the city's first daily paper. Alger Press closed in 1993 due to bankruptcy. What remains in this building is a huge factory space, composed of three storeys of red brick. It is resonant of Manchester's textile mills that later converted to lofts. This space has enormous potential. Unfortunately, the library was not purpose-built to utilise its space (Fig. 11) and the librarians were not involved in its design (Brabazon and Orfano 2011).

The remainder of the structure is a shell looking for a function (Fig. 12).

Two faculties were moved to downtown Oshawa: Education and Social Sciences and Humanities. Both use the Alger Press building for lectures. But the downtown strategy of moving into unused facilities has encountered difficulties. Renovating buildings does not

Fig. 11 - A library in space Photograph by Tara Brabazon

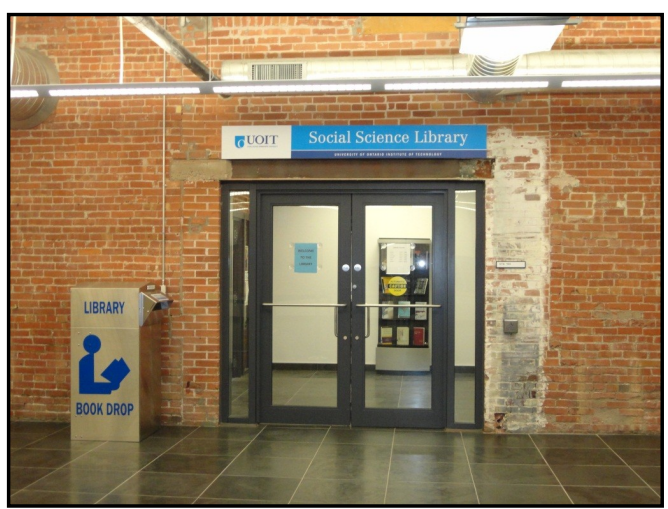


inevitably renovate a region or transform city imaging. Many, many buildings remain bordered up, with glass shards from broken windows peppering streets (Fig. 13).

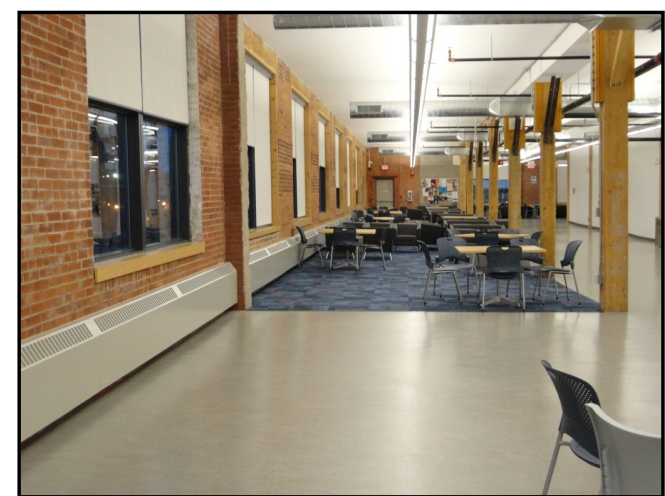

Fig. 12 - A shell for learning

Photography by Tara Brabazon

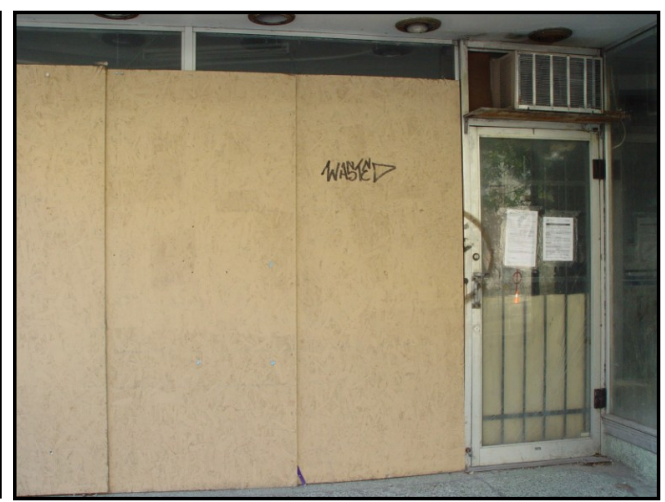

Fig. 13 - Disused space

Photography by Tara Brabazon

There is not a diversity of businesses and industries in the downtown. There are restaurants and coffee shops, but where are the bookshops, the music shops, the practice halls for musicians, supermarkets, web and fashion designers (Evans and Smith 2006)? A plurality of industries is required. There is also no functional hotel for visitors. The Hotel Genosha is a ghost of a building, decaying before the eyes of residents and visitors (Fig. 14).

Currently, there are few reasons for Oshawa's existence. It is excluded from Canada's 'technology triangle' of Cambridge, Kitchener and Waterloo. Joseph Leibovitz realized that even within the triangle, local allegiances often overshadow the unity of the triumvirate. Little attention has been given in the literature to the extent to which small cities and mid-sized localities, situated within close proximity to each other, may be reacting to the supposed transformation in urban political economy(2006 46).

While there are problems in building a productive regionalism, Leibovitz realized that the commercialization of university research, particularly when servicing governmental agencies, has created economic development (Leibovitz 2006, p. 48). Oshawa has been actively excluded from such a re-imaging strategy. The University's presence is not profound or structurally significant because it is disconnected from the wider social fabric. A tweet from May 19, 2012 captures this problem.

\section{Asked the \#GOTransit ambassador if he knew of a bus that goes from Oshawa Go to \#UOIT. He said "Sorry? U-O-what? I don't know what that is" \\ Expand}

Similarly, there are few opportunities for tourism. Small city/nations such as Singapore have activated a very effective tourism strategy (Chang 2006). But Oshawa is no Singapore. 

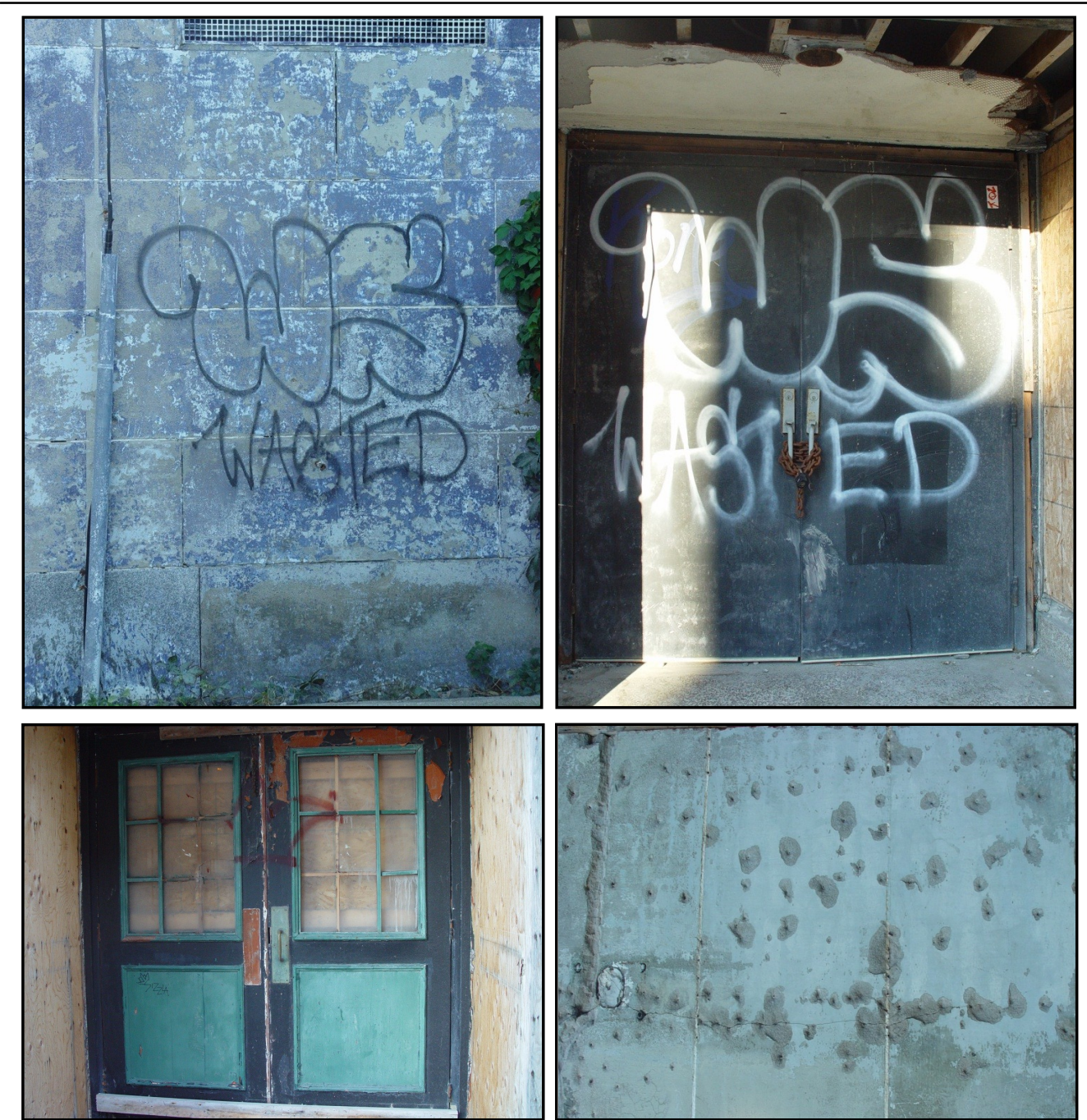

Fig. 14 - Hotel Genosha

Photograph by Tara Brabazon

Recognizing the exclusion of Oshawa from more active regional developments, the University is even more important to the economic and social survival of the city. There is a provocative and important relational maxim to consider: the smaller the city, the more important the university. John Hogan, the registrar at Newcastle University in the United Kingdom, verified the accuracy of this assumption.

Imperial [College London] is a fantastic institution, but if it closed, would London notice? Probably not. But if Newcastle closed, or Northumbria, Durham, Teesside or Sunderland [universities] closed, it would be a catastrophe for the local and the bigger region, because there's not a lot else going on in the North East. The relative importance of these universities is 
so much more important than some of the outstanding institutions you might find in London (Cunnane 2012, p. 8).

This role is increasingly crucial because - as Richard Muir from the Institute for Public Policy Research revealed - regional inequality increases when public spending declines. He suggests that, in the UK context, " $£ 1$ million output by a university generated a further $£ 1.38$ million for the wider economy" (Cunnane 2012, p. 8). While direct comparisons are difficult, it is an important argument to consider in and for Oshawa. In a declining economy, regional injustices increase and the economic role and significance of a university is amplified.

Yet ignoring such arguments and their consequences, controversial policies and police interventions have emerged that block the development of student and regional cultures. In September 2007, the Durham Regional Police entered the housing of university students. The City of Oshawa obtained warrants to search the homes. The police arrived unannounced and entered the properties without permission (but with the supposedly relevant authority).

The student returned from school to find police officers, a fire marshal, and a building inspector searching her personal possessions. A locksmith had picked the locks to her rental home to gain access. Her roommate was awakened from a nap when the officials entered her bedroom to search (City Raids Student Houses in Oshawa 2007).

The reason for such behaviour - or indeed the justification - was that the buildings were being used illegally as boarding houses. This treatment of renters who also happened to be students was also a symptom of a wider problem. The then President of UOIT stated that the "worst is over" (City Raids Student Houses in Oshawa 2007). He was incorrect.

In 2012, an attempt was made to create space for students, to enable the university to expand its facilities. Oshawa residents responded. Jeanette and Kevin McCurdy wrote to the newspaper expressing their displeasure.

This is a low-density, single-family home neighbourhood and should stay that way. If apartments were to be built here, surely they would become student housing and we should not have to deal with the same problems related to student housing that have plagued the residents at Simcoe and Conlin. Have we learned nothing from that debacle? I would expect that Planning Services and the Development Services Committee would have the insight and forethought to avoid such a huge and costly mistake (2012).

There are potent, divisive and destructive debates encircling Oshawa's housing and indeed the versions of the city's future. The reality is that the majority of students at UOIT are commuting to the campus. It is not a university dominated by scholars residing on or near the university's facilities. This pattern of commuting to college rather than living is a wider characteristic of universities in the Toronto region (Tamburri 2008). However it has particular consequences for Oshawa, as the students are needed as a key market for goods and services. The point is that they drive or ride to the campus for their classes and leave at the conclusion of their timetabled day. There is residential accommodation, but in comparison to other universities in North America and the United Kingdom, it is a much smaller proportion of scholars. Therefore, to refer to student housing or - more problematically - students as a "plague" on the region is not being honest. Oshawa is looking for new industries, reputation, branding, businesses, commerce, employment and opportunity. These students are providing not only a foundation for the future, but a pivotal model for survival. These residents must recognize that 'business as usual' in Oshawa is not an option. It is disingenuous to enjoy the money brought to the region 
by students, but disrespecting the carriers of those funds.

A key new problem is emerging as the first generations of scholars complete their degree. They are leaving the city upon graduation. One of the benefits of university cities is that the well-educated students remain for a period and contribute to the economy. However if the city is confronting such structural problems that there is no work, social life, facilities or reason to remain, then students leave the moment they receive their transcript. This is happening in Oshawa. The following Facebook update was offered from a graduating UOIT student on April 29, 2012.

\section{Good riddance Oshawa. Just the city though...I will miss all my friends terribly.}

\section{Like · Comment ' 30 minutes ago · 2 s}

Going to university in the city did not create an emotional connection to Oshawa. "Good Riddance" is not the foundation for a successful city imaging project. But this student's attitude is understandable. There is little employment and while General Motors still has a presence in the city, the number of workers and investment is declining. Further, how sustainable is a city imaging and branding based around the automotive industry in an era after peak oil?

There are clearly problems with housing. The way to build a downtown region is to bring people back into the area to live in it. The housing stock within walkable distance of the downtown is old, run down and inappropriate to the diversity of people that may wish to live there. It is very important that this housing stock is developed, as only when people reside in the city does it become living. Such an argument dominates the creative industries literature. Edward Glaeser believes that cities can offer profound sustainability. In Triumph of the City, he locates "engines of innovation" (2011, p. 1). To enable such strategies, Glaeser commits to "proximity, density and closeness" (2011, p. 6), showing that "traditional cities have fewer carbon emissions because they don't require vast amounts of driving" (2011, p. 14). Single family dwellings do not formulate such a model. Valuing the pedestrian life of London, New York and San Francisco, Glaeser recognizes that successful cities attract the best people who work collaboratively. They feature high quality educational institutions that are well administered. For Glaeser, "cities are green. Living in high densities and walking is a lot more environmentally friendly than living in a low-density suburb and driving everywhere" (2011, p. 267-268). Oshawa has none of these characteristics of a green city.

Considering the parking challenges in Oshawa, formulating strategies for pedestrians should be a priority. One model for Downtown Oshawa's development should be Manchester's Northern Quarter. It was a rough district of the city, known for prostitutes, drugs and gun crime. Rather than Madchester, the label that recognized the acid house and rave scene, the Northern Quarter was Gunchester. But by returning residents to the downtown, ensuring people can walk to work and university facilities and museums such as Urbis pepper the attendant streets, the space transformed. Cities change and will continue to change. But they also frame our experiences and our expectations. The question is how they are made liveable, walkable and sustainable.

Through globalization, cities are more predictable and standardized. Diversity is required to enable not only consumerism, but social justice. Frequently though, the contemporary city - at a policy and scholarly level - is 'about' consumption and competitiveness, not leisure and living. Glaeser's work is important because he reminds scholars that - for sustainability - cities must be more than a super (or meta) market for lifestyle goods. When the market economy becomes the unquestionable default position for all modes of 'development' - decentering not 
only 'the state' but 'the public' - cities become the shop window for a generation. The cafe culture is - at its most basic and cruel - an affluent suburban shopping centre. By drinking a coffee in an urban coffee shop, there is a desire that transcends caffeine. It evokes fashion, conscious consumerism and marketable bohemia. Through the café flaneurship, local coffee shop patrons also create a space where they can linger in the moment, at least temporarily suspending the press to squeeze more productivity out of their day and where they can act upon the paradoxical consumer desire to be out in public while retaining a detached anonymity. Rather than seeking an experience of communal solidarity, café flaneurs revel in the social spectacle of the coffee shop crowd (Thompson and Arsel 2004, p. 634).

The city is a siren's call for the problems and possibilities of the deindustrialized economy. City imaging policies and strategies displace leisure and work in preference for consumerism and infrastructure development. Citizens become shoppers. The key is how we ensure a history of place remains hooked into the social fabric. It is important to restate that every city cannot be world class. Regeneration at its worst creates standardization in an often desperate (and futile) attempt to satisfy, not the people already living in a city, but those they want to attract. In the end, neither is satisfied.

Oshawa is trapped between these goals, needing an industry yet complaining about the students that it brings. Besides housing challenges, Oshawa has deep transportation difficulties. The Go Train is an unwalkable distance from downtown. The question is why was the Oshawa Go Train situated in the outskirts of the city, requiring a bus from most places to even commence a journey? Now that students are in downtown, the lack of public infrastructure is creating social dysfunction. There is little parking in Oshawa - and what is present is expensive. Yet because the downtown was seen as poor and redundant in the modern Greater Toronto Region (Britton 2003), the public transportation infrastructure was not developed. A direct train from downtown Oshawa to Union Station would help the economic development of the entire region. Indeed, the development of a 'global city region' is reliant on it (Sassen 2001).

For Oshawa residents, there are vital challenges to address as local services decline. Living in a poor area where it is difficult to travel has consequences for health, with poor quality food and few places to exercise. In Canada, this lack of health-enabling infrastructure matters. The weather is not conducive to exercise. There is, for example, a correlation between where it rains and snows and obesity levels (Wainwright 2006). Therefore, what is required in areas of poor weather is access - at low cost - to high quality gymnasium facilities to assist health and wellbeing ${ }^{6}$. This mode of preventative health care policy also holds a strong social function. Martine Middleton realized that, "social patterns of movement, behaviour and meaning are derived from the physical and social interaction of city and place" (Middleton 1999, p, 117). Too often in economically deprived areas, there is poor access to gyms and healthcare, but plenty of junk food to purchase. That is the case in Oshawa.

Mobility is a mode of power and creates choices. The effectiveness of a city, in terms of social justice, can be evaluated in terms of the social and economic choices available for those who

6) A significant and new intervention in the development of health, wellness and fitness is a third tier city is the opening of Bolton One, attached to the University of Bolton campus. A partnership between the local council, the University of Bolton and the National Health Service, the goal was to create a culture of fitness for the young, the old, the immobile and those returning to fitness. The long-term imperative is to make physical culture and movement part of the daily life of Bolton residents. This initiative, opened in February 2012, provided not only a gym and exercise classes, but a swimming pool near the centre of Bolton, which had been without this facility for a decade. 
do not drive. The walkability of cities is important. It is a proxy to evaluate the degree of social and economic mobility. Whenever there is an assumption that 'everyone' has a car, there is a blind spot in providing important facilities and infrastructure. These assumptions are not sustainable and do block the development of social justice-fuelled improvements for those with different mobility needs. Driving is linked with a suite of ideologies, like freedom, speed and independence. Freedom of movement is a metaphor for freedom of citizenship. While some groups gain from automobility, other groups do not. As a population ages, new strategies for thinking about movement beyond a motor vehicle are required. Whenever there is a discussion about a decline in public services, particularly health care, libraries or education, it impacts on those with the least choices and the least ability to move through space.

The question remains: what are the motivations, modes and strategies to enact change in a city such as Oshawa? The university is not a saviour or resolution for structural problems. For example, David Bell and Mark Jayne, academics originally based in Stoke - a third tier city - at the University of Staffordshire, left their posts for second-tier city universities in Manchester and Leeds. They realized that, dwindling student admissions were a key factor - students appeared to be increasingly ambivalent about committing to the 'unglamorous' city of Stoke-on-Trent, perhaps attracted instead to the 'buzz' and increased job opportunities of larger metropolitan centres ((Bell and Jayne 2006, p. 246).

Ontario has too many universities. Each competes for a dwindling student population and indeed - market. The experience of living in a dynamic, exciting city with an attractive nighttime economy is an important factor when selecting a university. Oshawa has little to attract students. Therefore the scholars who have not achieved at satisfactory levels use it as the institution of last resort. High quality academic staff cannot be attracted to work in the city and university, and if they join, will not remain because of the inexperienced management, lack of international reputation, redundant tropes for online learning, and the absence of high quality graduate programmes. Even with these deep challenges and problems confronting UOIT, made more damning by the wider issues confronting Ontario's higher education system through a decline in funding, this university has provided a counterweight to unrelenting decline in the last decade, but has not scaffolded an economic recovery.

The question is what will happen next in the narrative of third-tier cities and their universities? Greg Richards and Robert Palmer confirmed that, cities of today face two choices. Either they develop to meet the challenges created by the pace of global change, or they resist the impulse for transformation and stagnate. At a time when economic systems are no longer predictable, in order to remain competitive, cities are turning to strategies that focus on their own innate resources - their histories, spaces, creative energy and talents (2010, p. 2).

For third tier cities, their industrial histories are economic anchors to redundant practices and processes and disconnected from current social and cultural opportunities. Their spaces reveal environmental damage, and the most talented residents move to global and second tier cities where there is expansive employment, educational and social opportunities. While Richards and Palmer aimed to promote 'eventful cities' rather than event management, they also recognized the importance in creating liveable cities, containing both social connections and emotional affiliations.

Social, economic and city imaging strategies align. Without economic development, the provision of services suffer. Therefore the social experience of living in a third-tier city also declines. Therefore city imaging is not only a branding exercise to bring business and events to a location. It is also a survival strategy. Bill Baker, in his Destination branding for small cities, 
confirmed that, in most cases, cities of this size can't always afford wide-ranging consumer research or high-profile advertising campaigns. Yet, there remains the need for them to stand out from the crowd in order to attract more visitors, more talented people, more inward, investment, and more new businesses (Baker 2007, p. 10).

Baker realized the paradox: we are living in "the most over-communicated period in history" (2007, p. 12), yet small cities have rarely 'managed' their brand and expressed their story (2007, p. 29). In an era of information glut, third-tier cities are invisible, marginal and marginalized. Therefore the final component of this article explores how the mobility of digitization and geosocial networking can medicate the lack of mobility and infrastructure in third tier cities. After the focus on decay and denial, the last section provides positive options to affirm difference.

\section{Conclusions: from social networking to geosocial networking}

This article has not followed the conventional path of social scientific research. Therefore a presentation of 'conclusions' is not appropriate. Instead, a combination of approaches from the humanities, including cultural and media studies along with theories from the creative industries literature, have filled some of the analytical gaps in scholarly understandings of third tier cities, particularly with attention to Oshawa. However, as a mode of conclusion and in a desire to invest the analogue spaces of these post-industrial cities with digital potential, geosocial networking offers potential.

A city is experienced through the senses. Traffic, buildings and the streets create a clash of sight and sound, touch and smell. As our bodies move through cities, our senses deliver information about threat and interest, alongside patterns of behaviour. Recognizing how we learn about urbanity, the view of graffiti artists like Wasted offer an alternative view (Fig. 15).

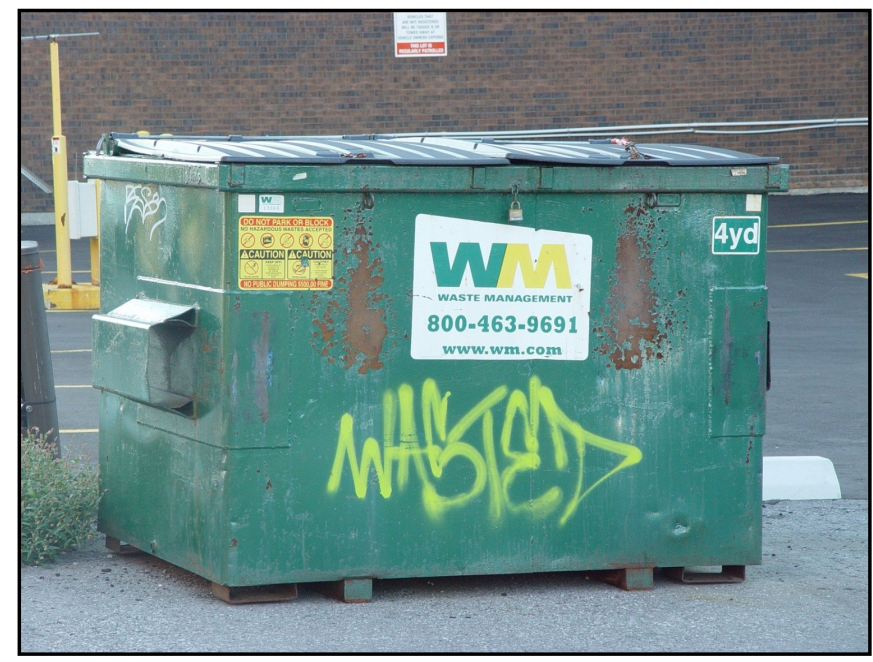

Fig. 15 - Urban Literacy

Photograph by Tara Brabazon

He or she is correct: much of downtown Oshawa is wasted. The question is how strategies for geosocial networking may enable development through a reinvestment in place. Analogue and digital lives are mediated and performed in a way that is suitable to each context. Screens are important. They separate analogue existence from digital performance. The read write web, often reified to the label of Web 2.0 , enables the active construction of a self. The web delocates and dislocates users from their physical environment. This means that users can be living in Oshawa, Singapore or Auckland, but can (re)emerge in a deterritorialized digispace of Facebook, Twitter and YouTube, chatting, watching and participating with other users around the world. This is a two-way movement. 
The internet, web and read-write web deterritorializes an audience from their physical environment.

The internet, web and read-write web reconstitutes us as an imagined online community.

A fascinating but unstable compromise is emerging between new and old ways of organizing space and identity. Geosocial networking is not only part of this process of deterritorialization and reterritorialization, but offers a new ontology and epistemology for urban environments.

A collision of social, political, technological and economic imperatives has meant that an investment in the local - including third tier cities - can have profound consequences for the development of businesses, social life and identity. John Quelch and Katherine Jocz, in their outstanding book All business is local: why place matters more than ever in a global, virtual world (2012), recognize the cost of marketers emphasising the global in decisions about production and consumption. They confirm that there are not only diverse modalities of place, but different modes of place, including geographical, physical, psychological and virtual. Digitization must now be considered when imaging or re-imaging a city or, indeed, any form of marketing. The Internet has also transformed marketing communications and democratized the brand knowledge and expectations of consumers around the world by accelerating the spread of word-of-mouth and viral advertising, more so even than television (2012, p. 9-10).

There is now a rapid dialogue between the diverse modes and meanings of place, a fast transference between local to regional, analogue to digital, physical to cloud-based computing, past and present. Quelch and Jocz realize that while consumers have shown a desire and willingness to purchase goods online, entering their credit card details into a portal, hyper-local advertising remains crucial, often delivered by supposedly globalized websites like Facebook and YouTube. Supposedly, the ability to make new friends and connect to people anywhere, regardless of their physical location, is one of the appeals of social media and social networking. However, one study found that half of Facebook friends are in the same metropolitan area; for teenage users, as many as 90 percent of friends are in the same area. People use Facebook more to solidify existing or geographically near relationships than to initiate or continue geographically distant ones (2012, p. 105). They ask that marketers "be intelligently local" (2012, p. 18). To provide one example, QR codes are a powerful mechanism to connect intensely local and physical spaces to just-in-time digitized information. When scanning the QR code from a poster in a shop window, the reader is able to gather and deliver digital information to their mobile phone about their actual location or interest. In this way, new connotations and associations can be hooked from digital environments and into a precise location.

Perhaps one of the most remarkable and surprising elements of digitization is geosocial networking. It logs the paradox of social media. While it is possible to contact and build relationships with users around the world, the bulk of 'friends' for most users on Facebook are geographically close. Similarly, mobile phones can connect users to anyone with another mobile phone. But actually, address books are filled with those in close spatial proximity. In other words, the platforms and applications that have the potential to reach every city and nation on the planet are deployed to communicate and share in local mode. Therefore with deterritorialization and disintermediation possible through the web and social media, it is remarkable how often social networking is actually geosocial networking: communicating with people within a restricted geographical area.

Geosocial networking is a sub-area of social networking, using the geographical features of 
mobile devices called global positioning systems. A phone, mobile tablet or computer recognizes a user's location and is able to locate a personal digital object in real space and time. Geographical applications include geo-coding and geo-tagging. The goal of these processes is to ensure that social media users can share their location with others. The means by which a location can be determined is via the internet provider, the email address being used, or self-disclosure where users inform Facebook, Twitter or FourSquare of a geographical location. Mobile phone tracking can reveal this information automatically. The combination of wireless delivery and geographical positioning software navigation creates an accessible and useful combination of technology, mobility and geography. Such applications as Google Maps and Google Earth provide huge amounts of information about cities. As Vassilis Kostakos confirmed, "the relationship between computers and space is a topic that has persisted throughout the various advances in computer science" (2010, p. 31). Although creating a positive and productive relationship between physical and digital spaces remains a challenge, the mobile phone is the conduit for its negotiation. The mobile phone is an odd object: personal, portable, customized by sound and vision through ring tones and wallpaper, individualized and creating a huge dependency on it from an owner. With the GPS chip in smartphones, location-based applications can search for data derived from a location. Further, such applications and functions like QR codes allow information to be directed - narrowcasted - to a particular website rather than the roulette wheel of Google.

Geosocial networking is not merely a digital tagging of people and locations. When a series of geo-coded or geo-tagged places are created, web maps are built. Group activity can then be logged around a place or event. There are many consequences of these applications. There are security issues: if a person logs their position, then others know that. For example in February 2010, a site called Please Rob Me was launched. Please Rob Me sourced data from Foursquare check-ins pushed to Twitter. The point of Please Rob Me was to show the cost of releasing too much information in public. But geosocial networking also allows groups to coordinate their actions. Flash mobs, riots and protests can be organized. Examples of geosocial networking services include Yelp, Gowalla, Facebook Places, Groupon and FourSquare. Yelp enables local searching of the web with attention to particular cities. Gowalla is a location-based social network that enables users to check into 'spots' or log 'trips' in a local community. Facebook Places arrived quite late in the social network's development, in 2010. Users checked in via mobile devices. Groupon is a group coupon that offers deals from local companies. A certain number of users must sign up for a deal and then it is 'on' and redeemable. Women in particular are the market for Groupon, with many 'deals' for health, fashion, beauty, fitness and food. FourSquare is the largest geosocial networking site. It was based on the success and expansion of smart phones with global positioning systems (West 2005). Users 'check in' via an application resident on the device. This 'check-in' releases points and badges for the user. Tiers of achievement on the basis of these locations are reached, including becoming the 'Mayor' of a FourSquare location.

The advantages of geosocial networking are that deterritorialized social networking is spatialized so that local users can share their interests in real space and time. But there are also major opportunities for local businesses, particularly those without more expansive branding or tourist opportunities (Evans 2011). I will provide a personal example to demonstrate this use. When in Oshawa, my husband and I lived in bed and breakfast accommodation. For a three day period, we were asked to relocate so that a wedding party could be housed. However, upon arrival at this temporary accommodation, we had no idea where we were. We had no car, no food and did not recognize our surroundings. I opened up FourSquare on an iPad, found our location, discovered local shops and restaurants, read reviews from users and found the best food, service and price within one kilometre. The great 
strength of geosocial networking is that even when our analogue selves do not know where we are, the smart phone or tablet has our coordinates and enables the discovery of geographically relevant information and services.

If my argument was placed in arithmetic: social networking + localism = geosocial networking. The value of geosocial networking is profoundly commercial. While social networking builds personal relationships, geosocial networking constructs relationships between consumers and business. Significantly, very few firms in Oshawa have instigated a geosocial marketing strategy. For areas that are facing economic challenges, these strategies are important. While there may be challenges with infrastructure and a lack of money for marketing, these free or freemium services (Anderson 2009) can source and connect consumers to businesses. QR codes provide information for customers either via print-based publicity materials - in newspapers, magazines or white or yellow pages - but also on the shop front of a business. To provide one example of its use: a restaurant can provide a QR code that not only links to a website presenting a menu, opening hours and specials but demonstrates the sourcing for all the ingredients. A bookshop, even when closed, can display a $Q R$ code that provides information to customers about the specific interests of the owner, author events and featured publications.

Certainly there are negativities. Geosocial networking is part of the long term movement to realign the internet and web from a freely available, public service into an individualized, customized, oversharing, business-led, shopping-enabled, e-commerce hub. The gift of the internet was deterritorialization. People can communicate from around the world. Citizens with disabilities could create new opportunities and communication options through a life on the screen. Racism and sexism could be questioned and managed in new ways. Now geosocial networking is creating location-aware applications so that residents in a particular place can receive discounts, find their friends in a restaurant, or check into a place and become a FourSquare mayor, a title without purpose, authority or status.

Social media are fragmented media. They create clusters, collectives and subcultures. The online future is perched somewhere between hyper-individual oversharing and global retweeting. Perhaps a less corporate shared localism is a better option, using the web to amplify social relationships within a particular space, place and community. FourSquare and Groupon are a pathway to that future, enabling the survival of local businesses in third-tier cities confronting economic and social challenges. For little or no cost, marketing can be as simple as claiming a FourSquare location or configuring deals for Groupon. Without an expansive city-wide strategy, small businesses can combine digitization and entrepreneurship to create an awareness of their services.

The positivity of geosocial networking in declining third tier cities is that mobile platforms can transform the relationship with the analogue environment, creating a liveable, walkable city. Much of the slow food movement was and is about buying local. Geosocial networking enables this imperative. But it also provides information about a city. QR codes provide an important example of a strategy to link a physical location with web-based information (Winter 2011). Such opportunities provide a way to invest our cities - particularly our downtowns - with greater interest. They become localized and sustainable. Digitization enables a richer analogue experience. This is the creation of a digital urban infrastructure that can overlay and solve many of the problems of analogue cities. Through geosocial networking, a first moment is emerging where digitization reinvests local places with meaning, and returns history to cities.

Place - location - remains important to people. This creates a paradox. Workers are expected 
to move anywhere and communicate with anyone in the world. The combination of a global growth in mobile communication and the domestication of hardware and software means that understandings of both time and place are transforming (Green and Haddon 2009). Yet a greater point needs to be explored. The strength of these mobile ties is still being questioned. Can geosocial networking be used to reinvest neglected places with meaning? As John Quelch and Katherine Jocz realized, "City planners are concerned with the 'legibility' of places - that is, people's ability to comprehend public places and to form mental maps that help steer them through these spaces" (2012, p. 33-34). One way to render locations legible is to use the resources of geosocial networking to offer digital stories of physical locations. If digital media are dug into the ground, then the built environment can also live in a cloud.

Geosocial networking requires particular characteristics: portable media, networked media, global positioning systems, location-conscious computing devices and information and media literate individuals who add content and meaning to a geographical space. Ostensibly, cities were designed to keep the poor from the rich and restrict the rights of some citizens to full participation in the political process. But by retrofitting analogue cities to provide information about the lived experience of the environment, then the injustices of the $19^{\text {th }}$ and $20^{\text {th }}$ century may not be healed, but at least can be addressed. A desire for social change may be enabled, not through shopping but thinking, and not through driving, but clicking while walking.

\section{References}

ANDERSON, B. (2006), Imagined Communities. London, Verso.

ANDERSON, C. (2009), Free: the future of radical price, New York, Hyperion.

ARNOLD, M. (1869), Culture and Anarchy, 1869, Authorama, Retrieved from: http:// www.authorama.com/culture-and-anarchy-1.html.

ALSOP, W. (2005), Will Alsop's SuperCity, Manchester, Urbis.

BAKER, B. (2007), Destination branding for small cities, Portland, Creative Leap Books.

BARNES, T., HUTTON, T. (2009), Situating the new economy: contingencies of regeneration and dislocation in Vancouver's inner city, Urban Studies, 46,5, Retrieved from: http://www.geog.ubc.ca/ tbarnes/pdf/PAPER_Situating_Vancouver's_new_economy.pdf.

BELL, D., JAYNE, M. (2006), Conceptualizing small cities, in Small cities: urban experience beyond the metropolis, eds. D. Bell and M. Jayne, Abingdon, Routledge.

BELL, D., JAYNE, M. (2006), Afterword: Sizing up small cities, in Small cities: urban experience beyond the metropolis, eds. D. Bell and M. Jayne. Abingdon, Routledge.

BIANCHINI, F. (1991), Re-imagining the city, in Enterprise and Heritage, eds. J. Corner and S. Harvey, London, Routledge.

BRABAZON, T. (2005), Liverpool Of The South Seas: Perth And Its Popular Music, Perth, University of Western Australia Press.

BRABAZON, T., MALLINDER, S. (2006), Popping the museum: the cases of Sheffield and Preston, Museum and Society, November, Retrieved from: http://www.le.ac.uk/ms/m\&s/ issue $\% 2011 /$ brabazon.pdf.

BRABAZON, T., MALLINDER, S. (2010), Branding Bohemia: community literacy and branding difference, City \& Time, 3, 2, Retrieved from: http://www.ceci-br.org/novo/revista/ docs2008/CT-2008-132.pdf.

BRABAZON, T. (2011), When bohemia becomes a business: City Lights, Columbus Avenue and a future of San Francisco, Human Geographies, 5,1, pp. 43-59, Retrieved from: http://humangeographies.org.ro/articles/51/5_1_11_4_brabazon.pdf.

BRABAZON, T., ORFANO, S. (2011), Tara talks with social science librarian Stephanie Orfano, Libsyn, December 11, Retrieved from: http://tarabrabazon.libsyn.com/webpage/taratalks-with-social-science-librarian-stephanie-orfano. 
BRASH, J. (2012), Downtown as brand, downtown as land: urban elites and neoliberal development in contemporary New York City, in Global downtowns, eds. M. Peterson and G. McDonogh, Philadelphia, University of Pennsylvania Press.

BRITTON, J. (2003), Network structure of an industrial cluster: electronics in Toronto, Environment and Planning A, 35, 6, pp. 983-1006.

BROWN, A., CRABBE, T., MELLOR, G., BLACKSHAW, T., STONE, C. (2006), Football and its communities: Final Report, London, Football Foundation, Retrieved from: http:// www.substance.coop/files/Football\%20and\%20its\%20Communities\%20Final\%20Report.pdf.

BUTLER, T., LEES, L. (2006), Super-gentrification in Barnsbury, London: globalization and gentrifying global elites at the neighbourhood level, Trans Institute of British Geographers, 31, 4, pp. 467-487.

CHANG, T. (2006), Tourism in a reluctantly small city-island-nation: insights from Singapore, in Small cities: urban experience beyond the metropolis, eds. D. Bell and M. Jayne, Abingdon, Routledge.

CITY RAIDS STUDENT HOUSES IN OSHAWA. (2007), Macleans, October 30, Retrieved from: http://oncampus.macleans.ca/education/2007/10/31/police-raid-student-houses -in-oshawa/

COLE, L. (2012), Regent closed after roof collapsed, Oshawa Express, Retrieved from: http://www.oshawaexpress.ca/viewposting.php?view=2384.

CORNFORD, J., and CHARLES, D. (2001), Culture cluster mapping and analysis: a draft report for ONE North East, Centre for Urban and Regional Development Studies, University of Newcastle upon Tyne, Retrieved from: www.campus.ncl.ac.uk/unbs/hylife2/lib/ files/4731report.pdf.

CUNNANE, S. (2012), 'Univer-cities' told to learn some home truths, Times Higher Education, May 3, p. 8.

D'ANDREA, C. (2012), The rise of downtown campuses, University Affairs, February 6 , Retrieved from: http://www.universityaffairs.ca/uptown-campuses-go-downtown.aspx.

ERICKCEK, G., McKINNEY, H. (2004), Small Cities Blues: Looking for Growth Factors in Small and Medium-Sized Cities, Upjohn Institute for Employment Research, Working Paper 04-100, Retrieved from: http://research.upjohn.org/cgi/viewcontent.cgi? article $=1117 \&$ context=up_workingpapers.

EVANS, G. (2005), Measure for measure: Evaluating the evidence of culture's contribution to regeneration, Urban Studies, 42, 5-6, 2005, pp. 965-978.

EVANS, L. (2011), Geo-Social Networks - A Local Business' Best Friend, ClickZ, March 16, Retrieved from: http://www.clickz.com/clickz/column/2034249/geo-social-networks-localbusiness-friend.

EVANS, Y., SMITH, A. (2006), Surviving at the margins? Deindustrialisation, the creative industries upgrading in London's garment sector, Environment and Planning A, 38, 12, pp. 2253-2269.

FARLEY, P., ROBERTS, M. (2011), Edgelands: Journeys into England's True Wilderness, London, Jonathan Cape.

GLAESER, E. (2011), Triumph of the city, London, Macmillan.

GREEN, N., HADDON, L. (2009), Mobile Communications, Oxford, Berg.

GREGORY, E., WILLIAMS, A. (2002), City literacies: learning to read across generations and cultures, London, Routledge.

GRIECO, M., RAJE, F. (2004), Stranded mobility and the marginalization of low income communities, paper for Urban Vulnerability and Network Failure, Manchester, SURF.

FEATHERSTONE, M. (2004), Automobilities, Theory, Culture \& Society, 21, 4-5, pp. 1-

24.

FLORIDA, R. (2005), The flight of the creative class, New York, Harper Collins.

HANDY, S. (2002), How the built environment affects physical activity, American 
Journal of Preventative Medicine, 23, 2 suppl., pp. 64-73.

HASLAM, D. (1989), Manchester England, London, Fourth Estate.

HAZIME, H. (2011), From city branding to e-brands in developing countries: An approach to Qatar and Abu Dhabi, African Journal of Business Management, 5, 12, pp. 47314745, Retrieved from: http://www.academicjournals.org/ajbm/PDF/pdf2011/18June/Hazime.pdf. HOLLANDS, R. (2002), Divisions in the dark: youth cultures, transitions and segmented consumption spaces in the night-time economy, Journal of Youth Studies, 5, 2, pp. 153-171. JAYNE, M. (2004), Culture that works? Creative industries development in a workingclass city, Capital and Class, 84, pp. 199-210.

KOSTAKOS, V. (2010), Space syntax and pervasive systems, in Geospatial analysis and modeling of urban structure and dynamics, eds. B. Jiang and $X$. Yao, London, Springer. KUNZMANN, K. (1995), Developing the regional potential for creative response to structural change," in Cities in competition: productive and sustainable cities for the $21^{\text {st }}$ century, eds. J. Brotchie, M. Batty and E. Blakely, Melbourne, Longman, pp. 286-294.

LANDRY, C., BIANCHINI, F. (1995), The Creative City, London, Demos.

LANDRY, C. (2004), The Creative City, London, Comedia.

LEADBEATER, C. (1999), Living on thin air, London, Viking.

LEIBOVITZ, J. (2006), Jumping scale: from small town politics to a 'regional presence'? Re-doing economic governance in Canada's technology triangle, in Small cities: urban experience beyond the metropolis, eds. D. Bell and M. Jayne, Abingdon, Routledge.

LEE, C., P. (2002), Shake rattle and rain: Popular music making in Manchester 19551995, Ottery St. Mary, Hardinge Simpole Publishing.

MACALUSO, G. (2012), Oshawa automotive capital of Canada, Windsor Star online, February 7, Retrieved from: http://blogs.windsorstar.com/2012/02/07/oshawa-automotivecapital-of-canada/. MANLEY, S. (1996), Walls of exclusion: the role of local authorities in creating barrier free streets, Landscape and Planning, 35, 2-3, pp. 137-152.

MARBER, I. (2000), The Food Doctor in the City: maximum health for urban living, London, Collins and Brown.

MARKUSEN, A., LEE, Y., DIGIOVANNA, S. (1999), Second-Tier Cities, Minneapolis: University of Minnesota Press.

MARVIN, S., MEDD, W. (2004), Metabolisms of Obecity: fat across bodies, cities and the sewers, paper for Urban Vulnerability and Network Failure, Manchester, SURF, April 29-30, Retrieved from: http://www.envplan.com/abstract.cgi?id=a37272. McCURDY, J., K. (2012), Proposed Oshawa zoning change not appropriate, Durham

Region.com, March 26, Retrieved from: http://www.durhamregion.com/oshawa/article/1324181. McINTYRE HOOD, M. (1968), Oshawa: Canada's Motor City, Oshawa, Alger Press.

MIDDLETON, M. (1999), Cities: resident readers and others, in Critical Textwork, ed. I.

Parker, Buckingham, Open University Press. MISENER, L. and MASON, D. (2006), Developing Local Citizenship through Sporting

Events, Current issues in tourism, 9, 4-5, pp. 384-398.

NANDY, A. (1983), The Intimate Enemy: loss and recovery of self under colonialism, Oxford, Oxford University Press. NOIMAN, K. (2009), Working out in a city that works you out, Milton Keynes, Author House.

O'CONNOR, J., WYNNE, D. (1996), From the margins to the centre: cultural production and consumption in the post-industrial city, Aldershot, Arena.

O'REGAN, K., QUIGLEY, J. (1998), Accessibility and economic opportunity, University of California, Berkeley, February, Retrieved from: http://emlab.berkeley.edu/ quigley/pdf/ access.pdf

PATTERSON, M. (2009), Inner-City Diet, Marston Gate, Amazon. 
PETERSON, M., McDONOGH, G. (2012), Global downtowns, Philadelphia, University of Pennsylvania Press.

PRAKASH, G. (1995), After colonialism: imperial histories and post-colonial displacements, Princeton, Princeton University Press

QUELCH, J., JOCZ, K. (2012), All business is local: why place matters more than ever in a global, virtual world, London, Portfolio Penguin.

REDHEAD, S. (2006), The Art of the Accident, Fast Capitalism, 2, 1, Retrieved from: http://www.uta.edu/huma/agger/fastcapitalism/2_1/redhead.html.

RICHARDS, G., PALMER, R. (2010), Eventful Cities: cultural management and urban revitalization, Amsterdam, Elsevier.

SAID, E. (1979), Orientalism, Ringwood: Penguin.

SALMAN, S. (2008), Brand of Gold, The Guardian, Retrieved from: http:// www.guardian.co.uk/society/2008/oct/01/city.urban.branding.

SANCHEZ, T. (2008), Poverty, policy, and public transportation, Transportation Research Part A, Policy and Practice, 42, 5, pp. 833-841.

SASSEN, S. (1991), The global city: the de-nationalizing of time and space, AEC, Retrieved from: http://www.btgjapan.org/catalysts/saskia.html.

SASSEN, S. (2001), Global Cities and Global City-Regions: A Comparison, in Global city-regions: trends, theory, policy, eds. A. Scott, Oxford, Oxford University Press.

SCOTT, A. (2001), Global city-regions: trends, theory and policy, Oxford, Oxford University Press.

SHORTHOSE, J., STRANGE, G. (2004), The new cultural economy, the artist and the social configuration of autonomy, Capital and Class, 84, pp. 36-48.

SIEGAL, B., WAXMAN, A. (2001), Third-tier cities: adjusting to the new economy, Reviews of Economic Development Literature and Practice, 6, Retrieved from: http:// www.eda.gov/ImageCache/EDAPublic/documents/pdfdocs/1g3/r_5f8_5fsiegel_2epdf/ v1/1g3lr_5f8_5fsiegel.pdf.

SPIVAK, G. (1988), In other worlds: essays in cultural politics, New York, Routledge. SPIVAK, G. (1990), The post-colonial critic, New York, Routledge.

STRAW, W. (2010), Cross-Border Visualities and the Canadian Image, Imaginations, 1, 1, Retrieved from: http://ejournals.library.ualberta.ca/index.php/imaginations/article/view/9759. SWEENEY, M., (2004), Second-Tier Cities: The Right Size at the Right Cost, Business Facilities, Retrieved from: http://www.facilitycity.com/busfac/bf_04_02_cover.asp.

TAMBURRI, R. (2008), Won't you stay, just a little bit longer, University Affairs, March 10, Retrieved from: http://www.universityaffairs.ca/wont-you-stay-just-a-little-bit-longer.aspx.

THOMPSON, C., ARSEL, Z. (2004), The Starbucks Brandscape and Consumers' (Anticorporate) experience of Globalization, Journal of Consumer Research, 31, 3, pp. 631-651.

UNIVERSITY OF ONTARIO INSTITUTE OF TECHNOLOGY ACT 2002, (2002),

Retrieved from http://www.e-laws.gov.on.ca/html/statutes/english/elaws_statutes_02u08_e.htm URRY, J. (2003), Global complexity, Cambridge, Polity.

WAINWRIGHT, M. (2006), Fat town' takes up cudgels in fight against the flab, The Guardian, August 29, Retrieved from: http://www.guardian.co.uk/medicine/ story/0,,1858729,00.html.

WALBY, S. (2003), The myth of the nation-state: theorizing society and politics in a global era, Sociology, 37, (3), pp. 529-546. WINTER, M. (2011), Scan me: Everybody' guide to the magical world of QR codes, Napa, Westsong Publications.

WALKER, M. (2010), Cities as creative spaces for cultural tourism: a plea for the consideration of history, Pasos, 8, 3, pp. 17-26.

WEST, N. (2005), Urban Tapestries: the spatial and social on your mobile, Proboscis, 
Retrieved from: http://proboscis.org.uk/publications/SNAPSHOTS_spatialandsocial.pdf. YOUNG, R. (1990), White mythologies, London, Routledge.

Initial submission: 25.02.2012

Revised submission: 18.04.2012

Final acceptance: 31.05 .2012

Correspondence: University of Bolton, Deane Road, Bolton, BL3 5AB, United Kigdom. E-mail: t.brabazon@bolton.ac.uk 
